UDC 621.396

\title{
FOG-CLOUD-STRATEGIES OF DYNAMIC TELECOMMUNICATION NETWORKS MANAGEMENT
}

\author{
Leonid O. Uryvsky, Olexander V. Budishevsky \\ Institute of Telecommunication Systems \\ Igor Sikorsky Kyiv Polytechnic Institute, Kyiv, Ukraine
}

\begin{abstract}
Background. Providing so called critical systems with reliable telecommunication service, and timely quality information by means of utilizing wireless sensor networks with mobile sensors, land telecommunication nodes, their efficient management along with simultaneous assurance of structural and functional connectivity of mobile sensors in response to their fast and unpredictable movement. Thus, such the methods development is challenging, that will allow dynamic network management on channel and network levels of OSI model, at the same time having the specified connectivity, operation time, service quality, information security enabled.

Objective. The purpose of the paper is description of the possible intellectualization strategies of high-performance sensor networks management based on utilization of dynamic telecommunication networks (DTCN) and computing FOGCloud infrastructure to increase performance, reliability, timeliness of information provisioning to critical systems functioning process and critical infrastructure components.

Methods. Alternative application strategies are synthesized concerning analysis of both the dynamic telecommunication network characteristics and dedicated FOG-Cloud-infrastructure configurations. DTCN control methodology is based on the fundamental automatic control theory tailored to DTCN objects.

Results. The paper studies the matters of alternative DTCN control utilization strategies in the form of the hybrid FOGCloud infrastructure generic control model and its adaptation method specifications to increase performance and reliability of dynamic telecommunication networks.

Conclusions. FOG technology is not an alternative to the Cloud infrastructure. In fact, FOG-infrastructure objects cooperate productively with Cloud infrastructure, especially in administration and data analysis, and such a collaboration generates the new application class. FOG networks distribute Cloud's intelligence down to network upper edge. So called data processing authority delegation takes place from aggregated cloud down to network peripheral.
\end{abstract}

Keywords: FOG-Cloud infrastructure.

\section{Introduction}

Cloud computing infrastructures are proven to serve fixed network users worldwide by means of globally distributed storage and computing resource. However, the sensor application development, in particular Internet of Things (IoT), requires IoT devices mobility support for several positions with geolocation and small delay for data processing. For that reason, the new platform called FOG computing is proposed to serve such requirements. Its main characteristic is the data processing performed nearby the data sources without the necessity to transmit it to large data centers just to process it and then transmit the results backwards.

The main difference of FOG computing technology is proximity to end users and their mobility support.

Due to that point FOG technology solves a series of the most common issues and enables the following:

- network latency decrease;

- endpoint mobility related issues resolution;

- fast communication channel restore;
- telecommunication resources cost saving;

- eliminates impact of significant geographic isolation of users and systems.

Research Goal is the description of the possible intellectualization strategies of high-performance sensor networks management based on utilization of dynamic telecommunication networks (DTCN) and computing FOG-Cloud infrastructure to increase performance, reliability, timeliness of information provisioning to critical systems functioning process and critical infrastructure components.

Object of the Research is hybrid FOG-Cloud infrastructure generic control model, its adaptation method to increase performance and reliability of dynamic telecommunication networks.

Subject of the Research is a set of methods for automated control of dynamic characteristics of model of dynamic telecommunication network composed with the usage of hybrid FOG-Cloud infrastructures. 


\section{Characteristic dynamic telecommunication networks}

Dynamic telecommunication networks (DTCN) are the components of critical systems, in other words, the systems that are the most vulnerable to damaging impacts. Hardware-software complex, information control, and telecommunication systems are key intelligent components of critical systems reliability and security enablement.

Critical systems can be used in several fields of application:

In healthcare applications the remote medical centers will be able to perform remote monitoring of patients through either video and audio devices or geolocation and tracking control devices.

- Ecological monitoring entails transmission of acoustic and video data that should be delivered within short period of time.

Traffic management systems enable motor-vehicle traffic controlling over highway system and deployment of traffic control service to obviate jam in case of emergency.

In case of emergency dynamic telecommunication system is capable to deliver to the rescue service representatives arrived to the site of an occurrence the detailed information about the emergency object, its characteristics and root cause.

Thereafter, a generic DTCN within the structure of critical system is a distributed and single element failsafe network of nodes performing the processing of control messages from authorities, acquisition of data on environment characteristics, and data transmission to the critical system operation center (CSOC) by means of delivery from node to node.

The specially equipped communication devices are used as the nodes of DTCN. Such devices aggregate radiocommunication tools, ground wired links to control objects, tools for computer processing of messages and control data [1].

Special communications equipment (SCE) can be installed in hard-to-reach places and used when a rapid reaction is required. That is, the SCE network protocols and operation algorithms must have the feasibility of network self-assembly.

The main characteristics of DTCN are as follows: implementation; Network self-assembly principle

$$
\text { - Mobility; }
$$

- Control mode and technique: hierarchical or distributed;

Data transmission with packet switching, when every node could be a router;

Communication distance and
transmission equipment power are defined by the spatial conditions according to the specific task implementation;

Radio-channel transfer rate depends on the distance between subscribers, wired channel transfer rate depends on the messages transmission demand within the range of physical environment resources.

The nodes may be established as fixed, however they must have a capability to move separately within the certain area having the network logical connectivity not destroyed, namely, to have a self-organizing structure.

The key functional and operational advantages of DTCN are the following:

- Capability of the network self-assembly and self-recovery. Self-assembly means automatic selection of network topology, new devices automatic connection to the network, packet transmission automatic routing over the network;

- Scalability of network with high density spatial allocation of nodes;

- High values of reliability and fail-safety metrics due to communication redundancy and availability of alternative data transmission routes;

- High energy efficiency;

- Network topology change tolerance and radio wave broadcasting environment characteristics change tolerance;

- Nodes' capability of common processing of data received and making decisions based on algorithms distributed among the structure of local (FOG) and global (Cloud) infrastructure.

DTCN is composed of software and hardware components.

Hardware component is a set of microprocessor devices equipped with transceivers, which establish the data transmission between these devices over the network.

Software component is an aggregation of characteristics of channel, network, and application levels, that enables data transmission from all the network nodes to specific nodes (base stations) connected with the control systems of critical objects.

In case of a node failure or a new node addition to the network, due to self-organizing structure the data flow from nodes to base station is being redistributed according to the network configuration changes.

DTCN architecture is challenging and it composed from independent self-organizing transponders (Fig.1) [2-3]. 


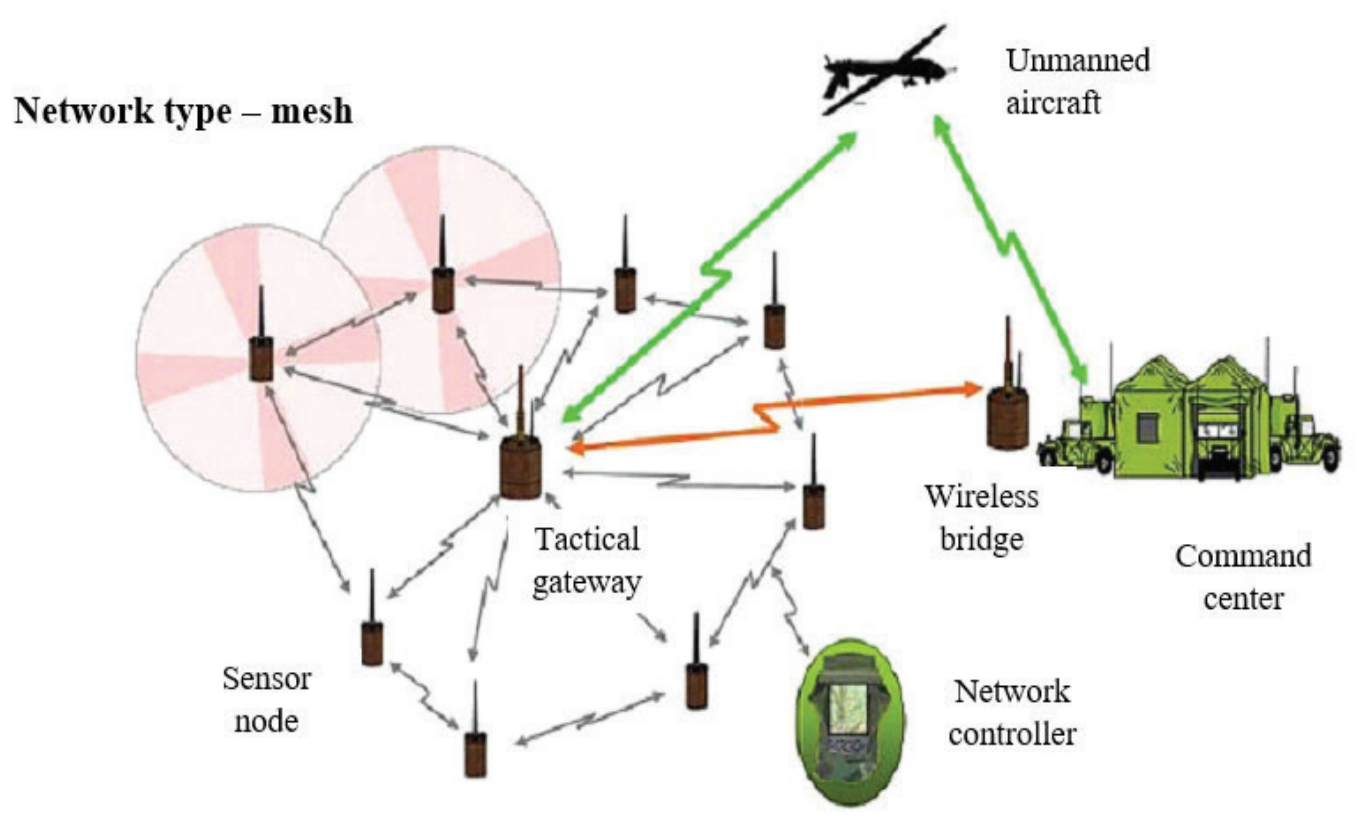

Fig.1. Architecture sample of dynamic telecommunication network with independent self-organizing transponders.

In general, nodes are situated in a random manner over the entire observation area. Each node can perform data acquisition and holds information on data transmission routing. Central node can communicate with the task manager via Internet or satellite. The protocol stack includes power and routing specifications, contains network protocols data, helps effectively communicate by means of wireless environment, and facilitates cooperation of the network nodes.

Analysis of DTCN's purpose, systematics, application samples, and management tasks affords suggestion of possible solutions for composition of functional subsystems of DTCN's management system. The proposed solutions are fundamentals of intelligent telecommunication network architecture that will allow organizing an adaptive architecture, to enable optimization of data transmission with defined quality of service; to automate its management process.

To solve management tasks for heterogeneous objects of DTCN with mobile nodes, the dynamic architecture of such network management system is proposed. Its special aspect is the intellectualization of decision-making process of control enablement techniques according to the network health on the ground of hybrid FOG-Cloud infrastructure.

To manage the self-organized DTCN effectively, the data flow routing functions are advisably to perform on the levels of topology management and routing management with the defined topology.

\section{Characteristic of FOG-Cloud Infrastructure Specifications and Applied Strategies}

The main issue of Cloud technologies is the large volume of IoT data, required to transmit to the centralized Cloud for processing, to elicit useful data (Insight), and then on the ground of that useful data to produce the control action and transmit this action's signal backwards to the environment of IoT actuators. It is quite time consuming (tens and hundreds of milliseconds that is frequently critical for IoT), it requires large computing capacity on centralized cloud and huge core network's bandwidth, lack of which increases the network latency even more.

FOG Computing is a new development stage of cloud computing, that decreases the latency, appeared during data transmission to the centralized cloud, and provides with the new opportunities of intelligent IoT devices creation.

FOG computing advantage is volume lowering of data transmitted to the cloud, that decreases the network throughput capacity requirements, ramps up the data processing rate, and reduces delay of decision making.

That is why FOG infrastructure objects take further development in applications required local realtime data processing, e.g. intelligent power supply systems (Smart Grid), intelligent transport systems (ITS), geophysical exploration survey, pipeline management, sensor networks of environmental monitoring systems, etc.

Main architectural differences of FOG infrastructure from Cloud infrastructure:

- $\quad$ Quality of Service (QoS) assurance by means of application dynamic adaptation to the network health status; 
- Feature of infrastructure objects' location awareness to maintain application operation stability of mobile terminals;

- $\quad$ Feature of context awareness, namely, an ability to detect nearby available resources to be utilized for application operation with internetworking capability.

Combination of Cloud and FOG technologies brings maximized value.

Some options of FOG and Cloud infrastructure junction are going to be considered next.

- FOG infrastructure autonomous hierarchy independent from Cloud infrastructure. Such configuration can be used in the cases when short duration of event-action, regulatory policy settings, military level security, and confidentiality are required. Moreover, the centralized Cloud might be inaccessible in some geographical locations, for instance, in case of seismic exploration, military operations, drone control, for some medical systems.

Local infrastructure of the FOG network is used for applications sensitive to latency, at the same time the Cloud is used for establishing balance of operational and business data processing. Use cases include uninterruptable power supply (UPS) devices monitoring, acceleration of mobile networks and Content Delivery Networks (CDN).

Most implementations of FOG systems in Industrial IoT (IIoT) usually include multiple levels of FOG network nodes.

Edge nodes usually perform data acquisition from sensors, data standardization, and control response assurance by sensors and actuators.

- $\quad$ Next level nodes perform data filtering, compression, and transition.

- Higher level nodes or nearby central Cloud usually perform data aggregation.

As the result, FOG networks distribute Cloud's intelligence down to network upper edge. So called data processing authority delegation takes place from aggregated cloud down to network peripheral. Otherwise, the central Cloud computing capacity, its intelligence, and core network capacity ought to have been multiple times increased. The intelligence distribution over FOG network can help solving that problem.

\section{Feature of FOG-Cloud-management Strategies}

To implement variety of possible multiple FOGCloud infrastructure management strategy, the unified FOG object's operation and management algorithm is proposed as shown on Fig. 2.

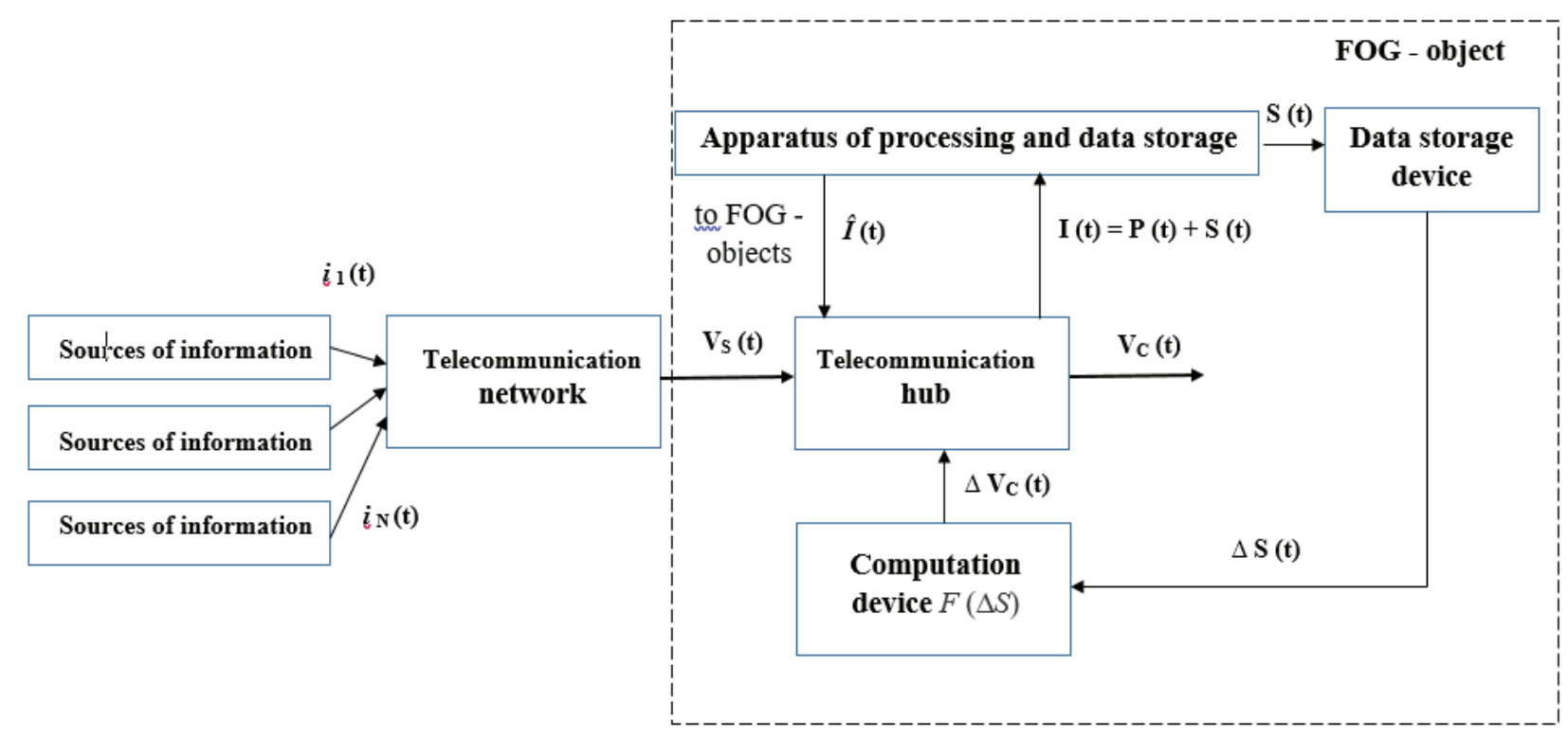

Fig. 2. Structure of unified managed FOG-object.

Each FOG-object is an element of Dynamic Telecommunications Network (DTCN).

Applied to the objects shown on Fig.1, its implementation place can be Tactical gateway and Command center.
As generic infrastructure presumes series of both Tactical gateways and Command centers, there can be series of FOG-objects in such infrastructure.

Let us turn to Fig. 2.

Information sources $i_{1}(t) \ldots i_{N}(t)$, intended to transmit over telecommunication network for processing in Apparatus of processing and data storage, that is part of 
FOG-object, are data acquisition devices marked as Sources of information: sensors, actuators, signal indicators.

Aggregated data from information sources is transmitted over telecommunication network to telecommunication hub with the input data rate $V_{\mathrm{S}}(t)$.

Task of the FOG-object is transmitted data processing and making decision according to processing results, and new information processing to the next FOGobjects.

Therefore, the transmitted data from telecommunication hub is received by the Apparatus of processing and data storage for further processing and buffered storage either temporary or permanent.

Thereby, summarized information $I(t)$ is composed of data for processing $P(t)$ and storage $S(t)$ :

$$
I(t)=P(t)+S(t)
$$

An idea of establishing FOG-object management consists in adaptive control of the symbol transmission output rate of the Telecommunication hub $-V_{C}(t)$ by means of managed resources of Dynamic Telecommunications Network, depending on the load of Data storage device $S(t)$.

Computation device reacts on the change $\Delta S(t)$ of load characteristics of Data storage device $S(t)$. Through the characteristic $F(\Delta S)$ the Computation device forms the action $\Delta V_{C}(t)$ on Telecommunication hub, having its output rate $V_{C}(t)$ adjusted.

So, in the local environment situation activation the load on sensors and other Sources of information grows.

As the result of data transmission rate increase over Dynamic Telecommunications Network, the information volume received by Apparatus of data processing and storage also grows.

If Apparatus of data processing and storage can manage the growing load of the FOG-object, then the volume fluctuation of the information $\Delta S$ accumulated in Data storage are compensated by the system of Computation device - Telecommunication hub that performs the workload change monitoring.

If computing capacity and/or storage volume is not sufficient for the given FOG-object, then part of the workload is relayed to other FOG-objects over the Dynamic Telecommunications Network channels.

Mathematic model of the described management process is as follows.

Static and dynamic characteristics instantiating the specifications of monitoring system performance are defined by the differential equation (DE), describing such a system operation [4].

In the case, shown on Fig. 2, the equation for DE of first order corresponding to the management system (in case of noise free condition) is written as

$$
\frac{d S}{d t}=\Delta S_{b}-\Delta S_{c} \cdot F(\Delta S)
$$

where $\Delta S_{b}$ - initial value of accumulated data in Data storage device (DSD) at the adjustment point;

$\Delta S_{c}$ - rejection limit of accumulation (maximum accumulation) for DSD;

$\frac{d S}{d t}$ - accumulated data increase rate in DSD;

$F(\Delta S)$ - characteristic of Computation device (Cd) reaction to the action $\Delta S$ aimed to produce the adjusting action on (TH) in form of $\Delta V_{C}(t)$.

Action $\Delta V_{C}(t)$ can be written as

$$
\Delta V_{C}(t)=\Delta S_{c} \cdot F(\Delta S),
$$

where $\Delta S_{c}$ - maximum data volume can be stored in Data storage device;

$\Delta S(t)$ - current data volume change in Data storage device;

$F(\Delta S)$ - normed discriminator characteristic of Computation device.

Modulation characteristic of Computation device $V_{C}(\Delta S)$ within the range of the control action $\Delta V_{C}(t)$ valuation change can be considered as linear:

$$
V_{C}=V_{C 0}+K \cdot \Delta S \text {. }
$$

Generic differential equation of automatic control system can be written as follows:

$$
\frac{p \cdot \Delta S}{\Delta V_{C \max }}+k(p) \cdot F(\Delta S)=\gamma
$$

where $\Delta V_{C \max }=K \cdot \Delta S$ - maximum adjusting detuning, inserted by the control circuit,

$\gamma=2 \pi\left(V_{C 0}-V_{S}\right) / \Delta V_{C \max }-$ normalized deviation of nominal transmission rate $V_{C 0}$ against the incoming data flow rate $V_{S}$.

If the non-delay corrective adjustment is used in Computation device, then the synchronous mode in the system is set when $|\gamma|<1$. In this case the steady-state difference $\Delta S(t)$ is measured within the range between $\Delta S_{\max }$ and $+\Delta S_{\max }$, depending on the initial deviate $\gamma$, and the value $T \approx \pi / \Delta V_{C \max }$ describes the invariable of transient processes establishment time.

If inertial integrating filter is used, then the synchronous mode holding range still reaches the values $\Delta V_{C \max }$; thus entry into the synchronism mode happens, if the initial deviate is less than the capture range $\gamma_{\text {capture }}<$ $2 \pi\left(V_{C 0}-V_{S}\right) / \Delta V_{C \max }$. Above the capture range the system might have been either in the synchronism mode or in the beats mode; and if $\gamma>1$, then beats always occur.

As the result, the action of the FOG-object monitoring system is a typical algorithm of automatic control system with predictable characteristics 
(predictable system). Such control corresponds both two strategies of FOG-Cloud infrastructure management selected in the section 2 .

\section{Conclusions}

1. FOG technology is not an alternative to the Cloud infrastructure. In fact, Fog-infrastructure objects cooperate productively with Cloud infrastructure, especially in administration and data analysis, and such a collaboration generates the new application class. FOG networks distribute Cloud's intelligence down to network upper edge. So called data processing authority delegation takes place from aggregated cloud down to network peripheral.

2. The following FOG and Cloud infrastructures combination options are preferred.

FOG infrastructure autonomous hierarchy independent from Cloud infrastructure. Such configuration can be used in the cases when short duration of event-action, regulatory policy settings, military level security, and confidentiality are required. Moreover, the centralized Cloud might be inaccessible in some geographical locations, for instance, in case of seismic exploration, military operations, drone control, for some medical systems.

- $\quad$ Local infrastructure of the FOG network is used for applications sensitive to latency, at the same time the Cloud is used for establishing balance of operational and business data processing. Use cases include uninterruptable power supply (UPS) devices monitoring, acceleration of mobile networks and Content Delivery Networks (CDN).

3. Studied the matters of alternative DTCN control utilization strategies in the form of the hybrid FOG-Cloud infrastructure generic control model and its adaptation method specifications to increase performance and reliability of dynamic telecommunication networks.

4. Alternative application strategies are synthesized concerning analysis of both the dynamic telecommunication network characteristics and dedicated FOG-Cloud-infrastructure configurations. DTCN control methodology is based on the fundamental automatic control theory tailored to DTCN objects.

\section{References}

1. Chebotareva D.V. Optimization of topology transmission network mobile communication with taking into account conflicting quality parameters // Herald of Lviv Polytechnic National University, Series of Radio Electronics and Telecommunication - 2013. - № 766. pp. 124 - 131. (in Russian)

2. Uryvsky L.O. Methods and means of ensuring the throughput and security of information communication systems in a dynamic environment. / Ensuring functional security of critical information and control systems. / Monograph. - Kharkiv: Konstanta, 2019. - 272 p. (in Ukrainian)

3. Lysenko Olexandr I. Increasing the efficiency of data gathering in clustered wireless sensor networks using UAV / Olexandr I. Lysenko, Miroslav K. Sparavalo, Olena M. Tachinina, Valerii S. Yavisya and Sergiy Ponomarenko // Information and telecommunication sciences. - 2020. - Vol. 11, no. 1. - pp. 59-70. - DOI: https://doi.org/10.20535/2411-2976.12020.59-70

4. Roland E. Best. Phase-Locked Loops: Design, Simulation and Applications (англ.). - 6th. - McGrawHill Education, 2007. (ISBN 978-0-07-149375-8).

\section{Уривський Л.О., Будішевський О.В.}

\section{Fog-cloud-стратегії управління динамічними телекомунікаційними мережами}

Проблематика. Забезпечення надійним зв'язком і своєчасною та якісною інформацією так званих критичних систем завдяки застосуванню безпроводових сенсорних мереж із мобільними сенсорами, телекомунікаційних наземних вузлів, ефективному управлінні ними із одночасним забезпеченням структурно-функціональної зв'язності мобільних сенсорів в умовах їх швидкого та непередбачуваного переміщення. Тому актуальною є розробка методів, які дозволять управляти динамічними мережами на канальному та мережному рівнях моделі OSI, забезпечуючи при цьому задані зв’язність, час функціонування, якість обслуговування та належний захист інформації в них.

Мета досліджень. Опис можливих стратегій інтелектуалізації управління високопродуктивними сенсорними мережами на основі використання динамічних телекомунікаційних мереж (ДТКМ) та обчислювальної FOG-Cloud інфраструктури для підвищення продуктивності, надійності, своєчасності інформаційного забезпечення процесу функціонування критичних систем та об'єктів критичної інфраструктури.

Методика реалізації. Альтернативні прикладні стратегії синтезуються на підставі аналізу якостей динамічних телекомунікаційних мереж та спеціалізованих форм FOG-Cloud-структур. Методологія управління ДТКМ грунтується на фундаментальній теорії автоматичного управління, адаптованої до об’єктів ДТКМ. 
Результати досліджень. Розглянуто альтернативні прикладні стратегії управління ДТКМ у вигляді узагальненої моделі управління комбінованої FOG-Cloud інфраструктури та характеристики методів іiі застосування для підвищення продуктивності та надійності динамічних телекомунікаційних мереж.

Висновки. Fog - технологія не $є$ альтернативою для Cloud - інфраструктури. Навпаки, об'єкти Fog-інфраструктури плідно взаємодіють з Cloud - інфраструктурою, особливо в адмініструванні і аналітиці даних, і така взаємодія породжує новий клас застосувань. Fog-мережі «розподіляють» інтелект «хмари» до верхніх кордонів мережі. Відбувається своєрідне делегування повноважень по обробці даних від централізованого «хмари» вниз на периферію.

Ключові слова: FOG-Cloud інфраструктури.

Урывский Л.А., Будишевский А.В.

Fog-cloud-стратегии управления динамическими телекоммуникационными сетями

Проблематика. Обеспечение надёжной связью, а также своевременной и качественной информацией так называемых критических систем благодаря использованию беспроводных сенсорных сетей с мобильными сенсорами, телекоммуникационных наземных узлов, эффективному управлению ими с одновременным обеспечением структурно-функциональной связности мобильных сенсоров в условиях их быстрого и непредсказуемого перемещения. Поэтому актуальной является разработка методов, которые позволят управлять динамическими сетями на канальном и сетевом уровнях модели OSI, обеспечивая при этом заданные связность, время функционирования, качество обслуживания и надлежащую защиту информации в них.

Цель исследований. Описание возможных стратегий интеллектуализации управления високопроизводительными сенсорными сетями на основе использования динамических телекоммуникационных сетей (ДТКС) и вычислительной FOG-Cloud инфраструктуры для повышения производительности, надёжности, своевременности информационного обеспечения процесса функционирования критических систем и объектов критической инфраструктуры.

Методика реализации. Альтернативные прикладные стратегии синтезуются на основе анализа свойств динамических телекоммуникационных сетей и специализированных форм FOG-Cloud-инфраструктур. Методология управления ДТКС базируется на фундаментальной теории автоматического управления, адаптированной для объектов ДТКС.

Результаты исследований. Рассмотрены альтернативные прикладные стратегии управления ДТКС в виде обобщённой модели управления комбинированной FOG-Cloud-инфраструктуры и характеристики методов её применения для повышения производительности и надёжности динамических телекоммуникационных сетей.

Выводы. FOG-технология не является альтернативой для Cloud-инфраструктуры. Напротив, объекты FOGинфраструктуры плодотворно взаимодействуют с Cloud-инфраструктурой, особенно в администрировании и аналитике данных, и такое взаимодействие порождает новый клас применений. FOG-сети «распределяют» интеллект «облака» до верхних границ сети. Происходит своего рода делегирование полномочий по обработке данных от централизованного «облака» вниз на периферию.

Ключевые слова: FOG-Cloud инфраструктуры. 